\title{
Short Communication: Diversity of sponges associated in seagrass meadows at coastal area of Pacitan District, East Java, Indonesia
}

\author{
EDWIN SETIAWAN ${ }^{1, \bullet}$, MUHAMMAD RIZKI CHODIANTORO ${ }^{1}$, GHULAM FATHUR INSANY ${ }^{1}$, \\ IWENDA BELA SUBAGIO ${ }^{1}$, NURUL KUSUMA DEWI ${ }^{2}$, FARID KAMAL MUZAKI ${ }^{1}$ \\ ${ }^{1}$ Department of Biology, Faculty of Science and Data Analytics (SCIENTICS), Institut Teknologi Sepuluh Nopember. Gedung H Biologi ITS, Kampus \\ Sukolilo, Jl. Teknik Mesin No.173, Keputih, Sukolilo, Surabaya 60111, East Java, Indonesia. Tel./fax.: +62-31-5963857, "email: edwin@bio.its.ac.id \\ ${ }^{2}$ Departmen of Biology Education., Universitas PGRI Madiun. Jl Setiabudi 85, Kartoharjo, Madiun 63118, East Java, Indonesia
}

Manuscript received: 3 May 2021. Revision accepted: 6 July 2021.

\begin{abstract}
Setiawan E, Chodiantoro MR, Insany GF, Subagio IB, Dewi NK, Muzaki FK. 2021. Short Communication: Diversity of sponges associated in seagrass meadows at coastal area of Pacitan District, East Java, Indonesia. Biodiversitas 22: $3105-3112$. Sponges are sessile organisms and aquatic filter feeders that play an important role in marine ecosystems. They are also secondary metabolite compounds that exhibit promising novel properties. Indonesia has been categorized as a hot spot for sponge diversity. Despite this fact, some Indonesian coastal areas, especially in the southern area of East Java, have not yet been comprehensively explored to understand its diversity and potential value. For this reason, we investigated species richness of sponges associated with seagrass meadows in the southern coastal area of Pacitan District, in East Java. Seagrass meadows are important coastal areas that have been recognized as buffer zones for sustainable marine conservation because it provides safe shelter and acts as a nursery for many fishes and other invertebrates, including sponges. We identified 16 genera out of 12 families from two selected beaches in Pacitan. Boring sponges belonging to the Clionaidea family were dominant in those areas, covering more than 20 percent of the total recorded specimens. Moreover, conspicuous boring sponges in this study can be used for further environment alert since this group plays a vital role and negatively impacts destroying the calcium carbonate of marine organisms.
\end{abstract}

Keywords: East Java Province, Indonesia, Pacitan District, Porifera, seagrass association, species richness

\section{INTRODUCTION}

Sponges are members of the Phylum Porifera (Grant 1836) and are a group of benthic or sessile organisms that mostly live in marine ecosystems. Sponges are also classified as animals that have a high species richness (van Soest et al. 2012). Approximately 9000 species have been successfully identified and a further estimated 11000 species have not yet been identified, making a total of more than 20000 species of sponges according to World Porifera Database (WPD) (van Soest et al. 2018). Sponges have been studied as an animal model for more than two decades to understand metazoan evolution and the origin of multicellularity because it is believed that sponges evolved from animal lineages that possess the most primitive tissue structure despite disputations that other primordial organisms such as ctenophore, placozoan and cnidarian possess the most primitive tissue structure (Dohrmann and Wörheide 2013; Pisani et al. 2015). Furthermore, sponges have been intensively researched due to their importance in marine ecosystems. Bell (2008) explained three important roles of sponges. Firstly, its impact on substrates where sponges play a role in reef creation, bioerosion, substrate stabilization, consolidation and regeneration. Secondly, sponges are involved in biogeochemical cycles such as carbon, silicon, oxygen and nitrogen which is recognized as benthopelagic coupling. Thirdly, sponge associations with symbiotic organisms facilitate primary and secondary productions, provision of microhabitat, and predation protection. Similarly, de Goeij et al. (2013) demonstrated that the survival of corals in areas with low amounts of nutrition is increased when it coexists with sponge communities. Sponges have been researched for its potential to be used as drugs. Perdikaris et al. (2013) in their review prioritized sponges to be researched for natural products due to the wide range of bioactive components, chemical components and secondary metabolites discovery from sponges that possess potential pharmaceutical applications. Other preliminary researches have also found that sponges have the potential to be used as drugs for treating diseases such as cancer, viral diseases, malaria, and inflammations (see review from Anjum et al. 2016). In addition, symbiotic organisms in sponges such as microbes are a potential source of nutraceuticals (Kim and Dewapriya 2012).

Located in a tropical region, Indonesia is understood to possess a huge diversity of marine resources (Edgar et al. 2017), in particular sponges, as components of marine ecosystems such as seagrass meadows (Becking et al. 2013a,b; Van Soest and De Voogd 2015; Calcinai et al. 2016, Maas et al. 2020). Several studies found sponge associations with seagrass meadows in the Caribbean region, for example, Halichondria melanadocia sponge and Thalassia testudinum seagrass (Archer et al. 2018), 
Clathria schoenus, Chondrilla caribensis forma caribensis, Clathria sp, Tedania klausi, Amphimedon erina sponges, and Thalassia testudinum seagrass (Wulff 2008). The association between sponge and seagrass communities is mutually beneficial. Sponges are able to provide nitrogen and phosphorus as a source of nutrition for seagrass, while seagrass transfer nutrients, become carbon storage, and stabilize sediments for sponges. Despite the fact that significant growth of seagrass and sponges does not cause competition, sponges still produce secondary metabolites normally to protect themselves from predators (Archer et al. 2015). In contrast to the Caribbean, there are few studies on sponge diversity and seagrass meadows in the IndoPacific region. Hitherto, the recorded species in the IndoPacific include Spirastrella inconstans, Cliona celata, Axinella flabelliformis, Axinella durissima, Callyspongia diffusa, Gelliodes fibrous, Sigmadocia fibulata, Haliclona implexa, Haliclona exigua sponges and Cymodocea sp., Halophila ovalis, and Cymodocea serrulata seagrasses found in India (Prabhakaran et al. 2013; Sivaleela et al. 2013) also Phoriospongia sp. and Toxochalina sp. sponges and Posidonia australis seagrass found in Australia (Demers et al. 2015) and several other sponge and seagrass species found in Pulau Seribu, Indonesia (Ismet et al. 2017). Due to the few studies conducted in the Indo-Pacific region despite its high sponge diversity, more explorations are needed in this region. Therefore, Pacitan, located on the southern coast of East Java, has been selected for this study since this region has been recognized to possess many marine natural resources (Pianto 2017). The diversity of sponges has not yet been thoroughly identified especially sponges in seagrass meadows. Moreover, records of sponges in seagrass meadows and their associations are necessary to be investigated for sustainable management of marine biota and provide information that is beneficial for ecological and economical values.

\section{MATERIALS AND METHODS}

\section{Study area}

This research was conducted in the southern part of Tawang beach $\left(8^{\circ} 15^{\prime} 37.80^{\prime \prime} \mathrm{S}, 111^{\circ} 17^{\prime} 20.86^{\prime \prime T}\right)$ and the southern part of Pidakan beach $\left(8^{\circ} 15^{\prime} 12.87^{\prime \prime} \mathrm{S}\right.$, $\left.111^{\circ} 14^{\prime} 36.21^{\prime \prime} \mathrm{T}\right)$, located in Ngadirojo sub-district, Pacitan District, East Java, Indonesia between 11-12 May 2018 and 15-16 August 2018 (Figure 1).

Tawang locality possesses bays that are more sheltered from waves than Pidakan. Tawang locality is categorized as a fine sandy beach with a mesh substrate between 0.063 $2 \mathrm{~mm}$ and mud with a substrate mesh ranging from 0.063 to $<0.004 \mathrm{~mm}$ and possesses a relatively moderate wave (Figure 2.A). In contrast, Pidakan locality is a rocky shore that has a lot of rock substrate with a substrate mesh between 2 and $16 \mathrm{~mm}$ and possesses a relatively large wave (Figure 2.C). Moreover, seagrass meadows in Tawang beach consist of Cymodocea rotundata, Thalassia hemprichii, Halophila ovalis (Figure 2.B), whereas seagrass meadows in Pidakan beach solely consist of Thalassia hemprichii (Dewi and Prabowo 2015; Dewi et al. 2019) (Figure 2.D).

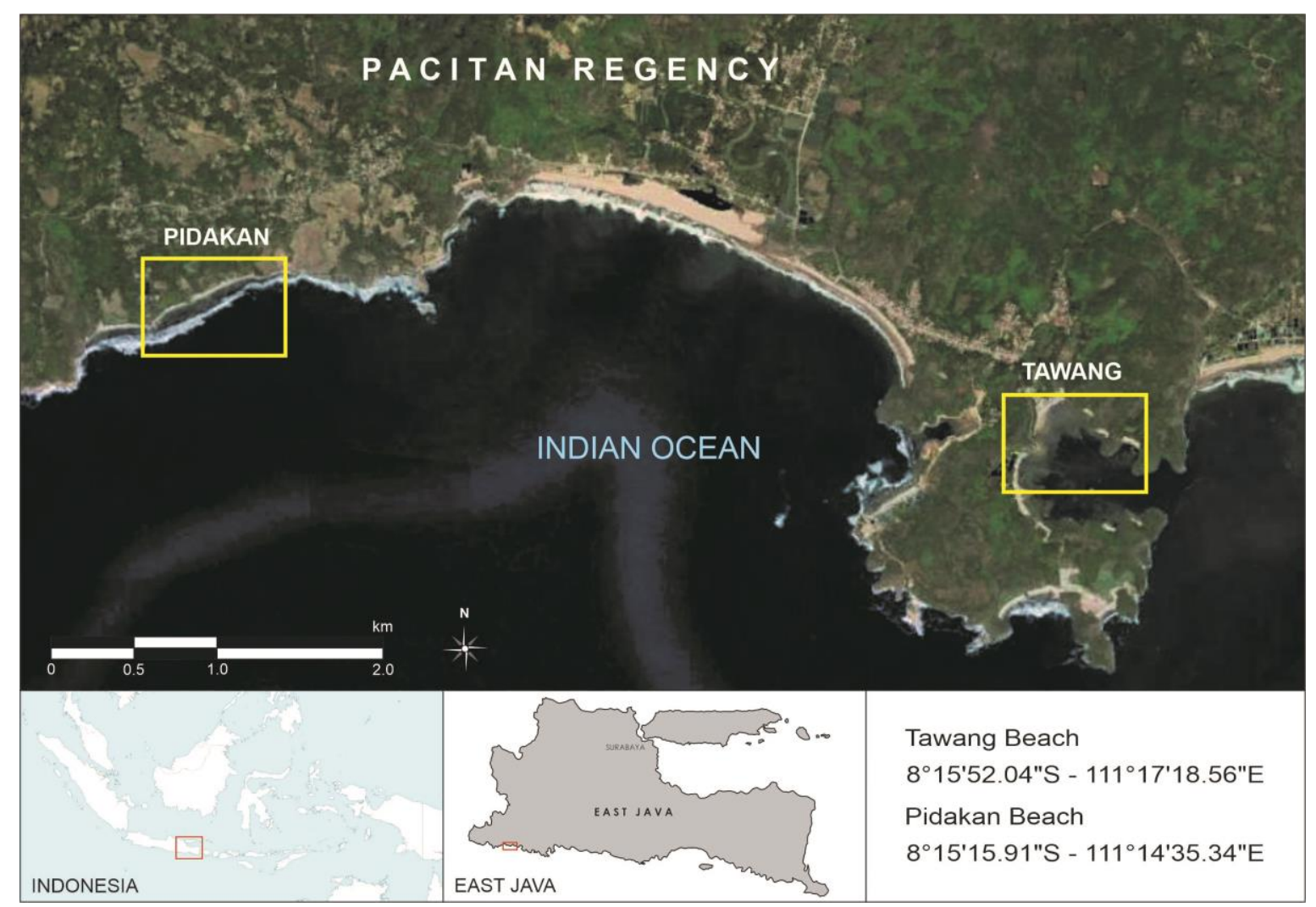

Figure 1. Location of Pidakan and Tawang beaches in Ngadirojo Sub-district, Pacitan District, the southern part of East Java, Indonesia 


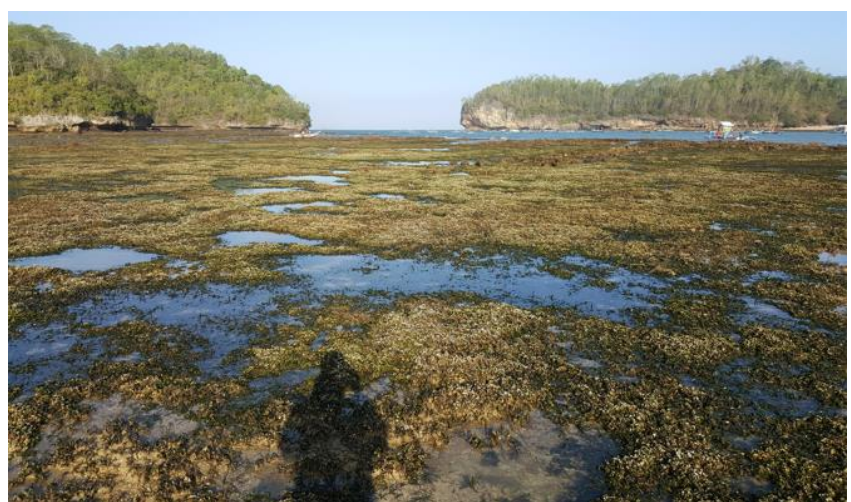

$\mathbf{A}$

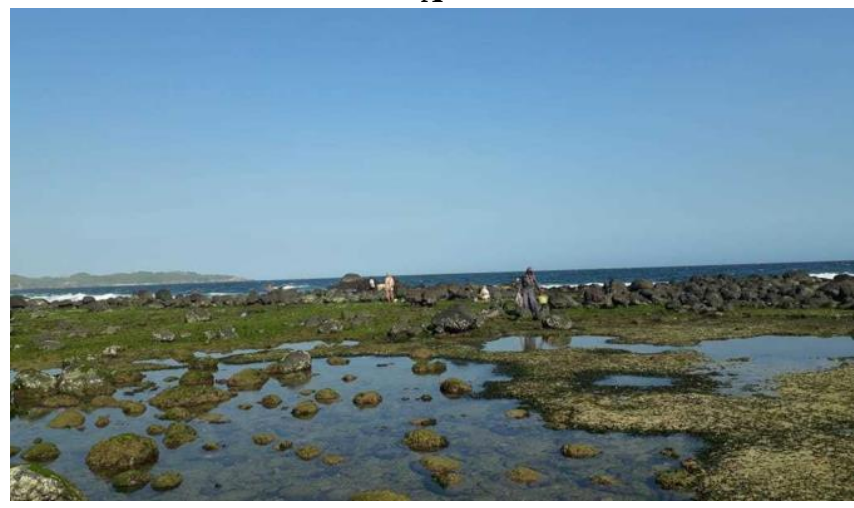

$\mathbf{C}$

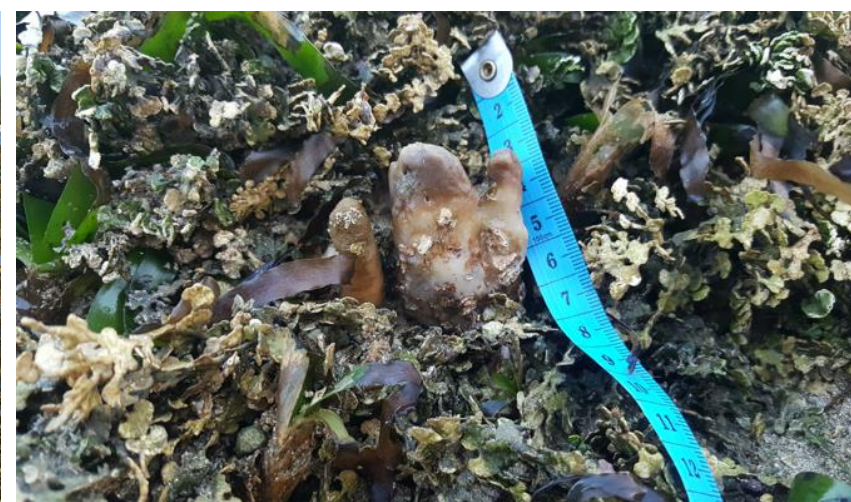

$\mathbf{B}$

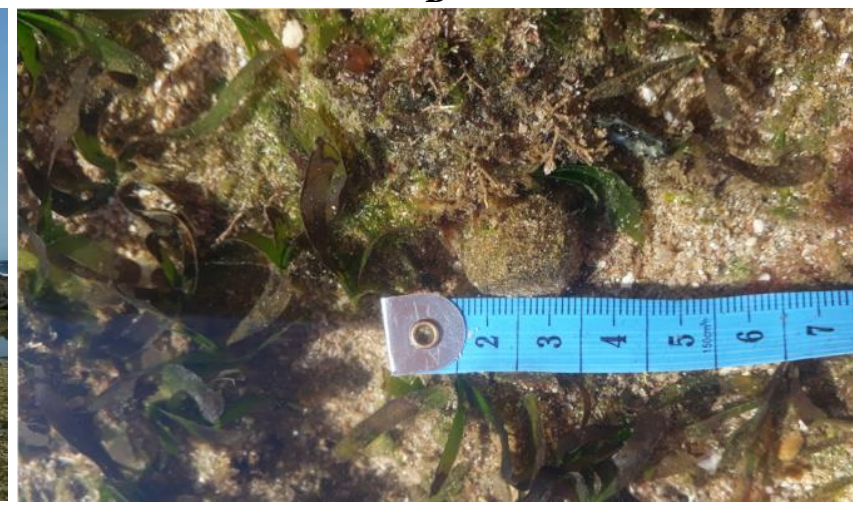

$\mathbf{D}$

Figure 2. A. Locality of Tawang beach; B. Associative sponge in seagrass meadows of Tawang beach; C. A locality of Pidakan beach; D. Associative sponge in seagrass meadows of Pidakan beach

\section{Procedures and data analysis}

Sampling and observation of morphological features

Samples of sponges were collected by hand in the intertidal zone of the beaches during a low tide (approximately 0-50 cm height). Samples were taken from the substrate and documented using a camera. The morphological characteristics recorded were shape, color, size and the environment around the sponge. The samples were rinsed three times with ethanol $96 \%$ and preserved at the Zoology and Animal Engineering Laboratory, Department of Biology, Institut Teknologi Sepuluh Nopember, Surabaya, Indonesia.

\section{Identification phase with microscopic features}

According to Hooper (2000), the identification of sponges requires two forms of histological preparation. The first is spicule preparation to determine the diversity of spicules in the skeleton and the second is preparation of thick section through the sponge tissue to determine the structure of the skeleton, the structure of the water-canal system, and other aspects of histology. Bleach digestion was used for the spicule preparation. In addition, small fragments of 'tissue' were placed in sample bottles, and a small quantity of sodium hypochlorite was added. After a short period of time, the organic components dissolved, leaving only the mineral skeletons. It was then rinsed three times using distilled water and a final wash of $70 \%$ ethanol was carried out to preserve spicules. Thick tangential and perpendicular hand-cut sections of $1.0-1.5 \mathrm{~mm}$ were procured from a preserved fragment in order to examine their skeletal arrangement. Sections were placed onto a glass slide and left to dry. Clean spicule suspensions were then pipetted onto a glass slide and covered with a coverslip and left to dry. Both spicules and skeletons were then mounted with Entellan ${ }^{\circledR}$ | 107960-Merck Millipore. After the microslides were completely dried, observations were conducted using a compound microscope, Olympus ${ }^{\circledR}$ CX31 and Optilab "Filter Upgrade Edition" with a magnification of 40X and 100X.

\section{RESULTS AND DISCUSSION}

\section{Boring sponges' dominance}

Thirty (30) specimens from 16 species were sampled from the two sites of this study (Table 1, Figure 3). Spheciospongia inconstans was the dominant species recorded on both sites. A larger number of S. inconstans was found in Pidakan beach presumably due to the rocky substrate of Pidakan beach. Thus, Pidakan beach is more suitable for S. inconstans, categorized as Clionid "boring sponge" on rocks, corals, or limestone substrates. Boring sponges break down calcium carbonate substances, converting them to fine substrates and in turn these converted fine substrates provide new resettlement for other marine organisms (van Soest et al. 2018). Besides its role as bioeroders, Nava et al. (2018) demonstrated that the 
domination of Clioniid "boring sponge", in particular Cliona vermifera, on coral rubble substrates in Mexico indicated unusual high records of water temperature coinciding with bleaching and mortality of corals, presumably due to the El Niño event. For this reason, the distinction from this study of $S$. inconstans in the two sites can be used as a bioindicator to estimate the physiochemical condition of Pacitan coast in future studies, for example, the effect of ocean acidification or anthropogenic activities at the localities. The presence of other species such as $P$. bacca at the two sites corroborates that this "ball or moon" sponge, is a conspicuous sponge that inhabits a broad range of marine ecosystems from reefs, shores, mangroves, and marine lakes (Becking et al. 2013a; Santodomingo and Becking 2018).

\section{Ecotypes and phenotypic plasticity}

We discovered that $S$. inconstans had two different forms namely encrusting and massive (Figure 4.A and B), which may be related to discrepancies in waves, the osculum of ecotypes, substrates, and turbidity at the two different localities. $S$. inconstans in massive form is more adaptive to rocky substrates and moderate to harsh ocean waves in Pidakan beach, whereas $S$. inconstans in encrusting form is more adaptive to fine sand, high turbidity and low ocean wave in Tawang beach. The occurrence of two distinct ecotypes is obvious because sponges tend to possess phenotypic plasticity (Calcinai et al. 2013; Guardiola et al. 2016) caused by survival efforts and adaptation to surrounding environments. Similarly, a change in the morphology of sponges is the result of local conditions such as water movement, light penetration, substratum suitability and competition for space in the habitat of the sponge (McDonald et al. 2002). A study on another intertidal sponge namely Biemna fortis, which is also a kind of Clionid sponge, discovered different growth forms between two locations (Dahihande and Thakur 2017). They reported that $B$. fortis that inhabited environments with high levels of suspended particles have a partially buried growth form and is in contrast to $B$. fortis that inhabited environments with low levels of suspended particles which have a massive growth form. In addition, because substrates are also important to the anchorage and stability of sponges, other ecotypes of $B$. fortis are revealed. Usually, $B$. fortis living in an area with strong tidal currents and grew in a fine or sandy environment utilize surrounding hard substrates to anchor against waves. If $B$. fortis grew in a less turbulent environment, their growth form is modified to elevate branches and grow above substrates.

\section{Shallow water sponges and seagrass meadows relationship}

Our results corroborate with the study conducted by Hadi et al. (2018) who recorded shallow-water sponges in intertidal zones of the southern coast of Java and the recorded species was similar to our study (Table 2). The species included were $S$. inconstans, Haliclona sp. and Callyspongia sp. that grew in the intertidal zone (less than 200m) and even Callyspongia sp. from Banyuwangi beach that inhabited a sandy substrate type associated with the $T$. hemprichii seagrass habitat. Furthermore, when we compared our results to other studies by Sivaleela et al. (2013), Prabhakaran et al. (2013), Demers et al. (2015) and Ismet et al. (2017) two genera: Calyspongia and Haliclona were also discovered in the other ecosystems with seagrass meadows (Table 2).

Table 1 Number of recorded sponges from the two localities of this study

\begin{tabular}{|c|c|c|c|c|c|c|c|c|}
\hline $\begin{array}{l}\text { Class/ } \\
\text { Subclass }\end{array}$ & Order & Family & Species Indication & $\begin{array}{l}\text { Tawang } \\
\text { Beach }\end{array}$ & Form & $\begin{array}{c}\begin{array}{c}\text { Pidakan } \\
\text { Beach }\end{array} \\
\end{array}$ & Form & Total \\
\hline \multicolumn{9}{|l|}{ Demospongiae } \\
\hline \multirow[t]{13}{*}{ Heteroscleromorpha } & \multirow[t]{3}{*}{ Axinellida } & Axinellidae & Axinella sp. & 2 & B & $X$ & $\mathrm{~B}$ & 2 \\
\hline & & \multirow[t]{2}{*}{ Raspailiidae } & Raspailia arbuscula & $\mathrm{X}$ & $\mathrm{E}$ & 2 & $\mathrm{E}$ & 2 \\
\hline & & & Raspaciona sp. & 1 & M & $\mathrm{X}$ & M & 1 \\
\hline & \multirow[t]{2}{*}{ Clionaida } & \multirow[t]{2}{*}{ Clionaidae } & Cervicornia sp. & 1 & B & $\mathrm{X}$ & $\mathrm{B}$ & 1 \\
\hline & & & $\begin{array}{l}\text { Spheciospongia } \\
\text { inconstans }\end{array}$ & 2 & M & 5 & $\mathrm{E}$ & 7 \\
\hline & \multirow{4}{*}{ Haplosclerida } & Callyspongiidae & Callyspongia sp. & $X$ & B & 3 & $\mathrm{~B}$ & 3 \\
\hline & & \multirow[t]{2}{*}{ Chalinidae } & Haliclona sp. & $X$ & M & 1 & M & 1 \\
\hline & & & Dendroxea sp. & 1 & M & $X$ & M & 1 \\
\hline & & Petrosiidae & Petrosia sp. & $\mathrm{X}$ & M & 2 & M & 2 \\
\hline & Poecilosclerida & Myxillidae & Myxilla sp. & $\mathrm{X}$ & $\mathrm{E}$ & 1 & $\mathrm{E}$ & 1 \\
\hline & Polymastiida & Polymastiidae & Trachyteleia sp. & $X$ & M & 1 & M & 1 \\
\hline & Suberitida & Suberitidae & Homaxinella sp. & 1 & M & $\mathrm{X}$ & M & 1 \\
\hline & Tetillida & Tetillidae & Paratetilla bacca & 2 & M & 1 & M & 3 \\
\hline \multirow[t]{4}{*}{ Verongimorpha } & \multirow[t]{2}{*}{ Chondrillida } & \multirow[t]{2}{*}{ Chondrillidae } & Thymosiopsis sp. & 2 & $\mathrm{E}$ & $\mathrm{X}$ & E & 2 \\
\hline & & & Chondrilla sp. & $\mathrm{X}$ & & 1 & E & 1 \\
\hline & \multirow[t]{2}{*}{ Chondrosiida } & \multirow[t]{2}{*}{ Chondrosiidae } & Chondrosia sp. & $\mathrm{X}$ & B & 1 & $\mathrm{~B}$ & 1 \\
\hline & & & & 12 & & 18 & & 30 \\
\hline
\end{tabular}

Note: Remarks on Form, B: Branching; E: Encrusting; M: Massive 


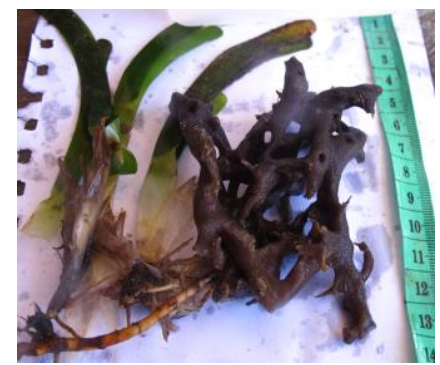

A

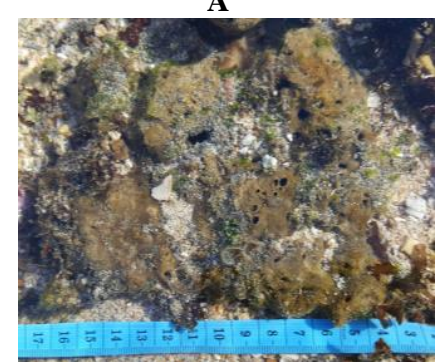

$\mathbf{E}$
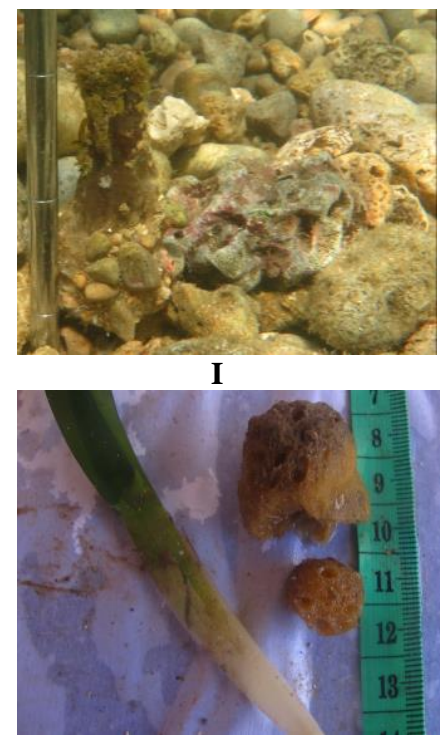

M

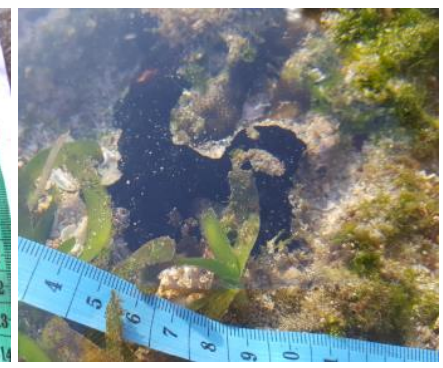

B

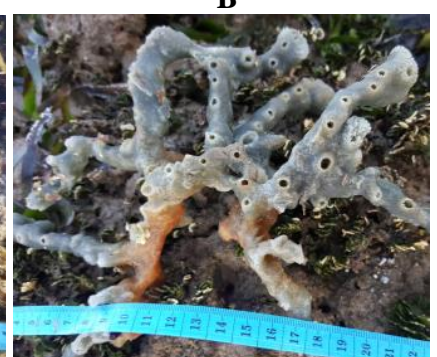

F

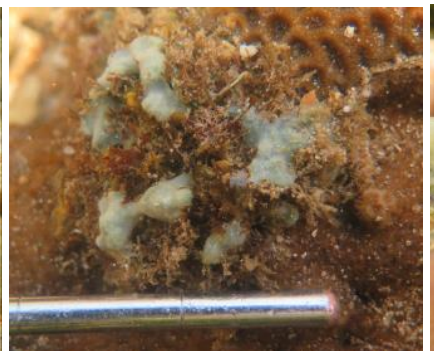

J

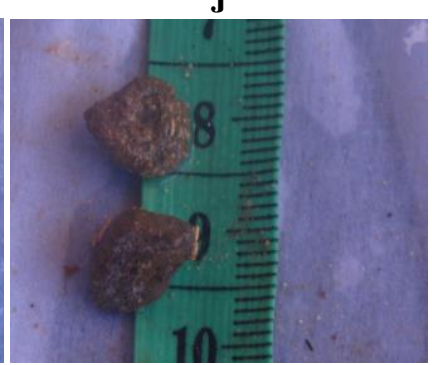

$\mathbf{N}$

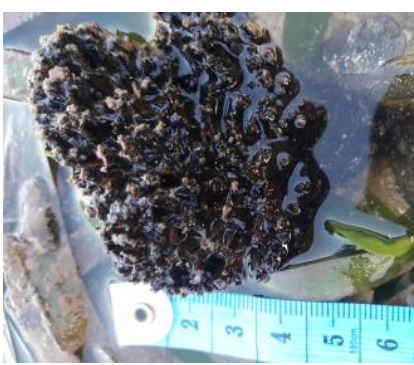

C

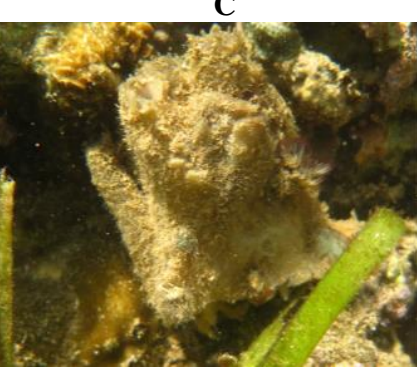

G

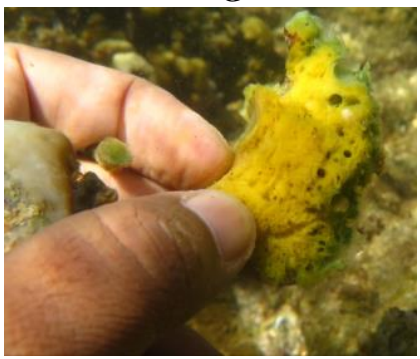

K

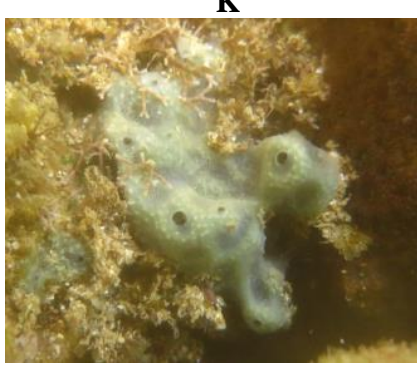

$\mathbf{O}$

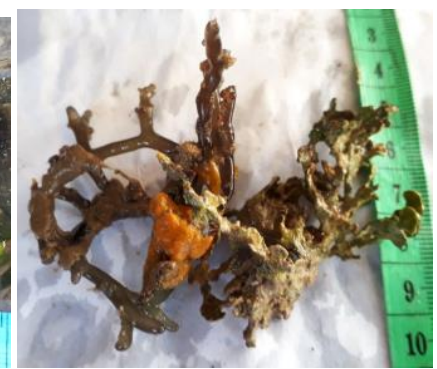

D

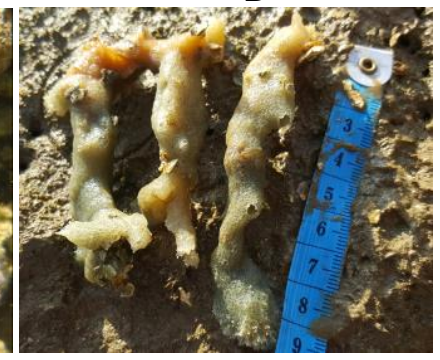

H

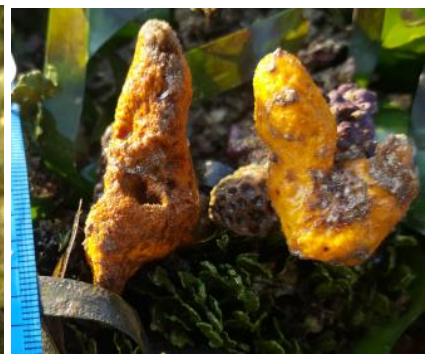

L

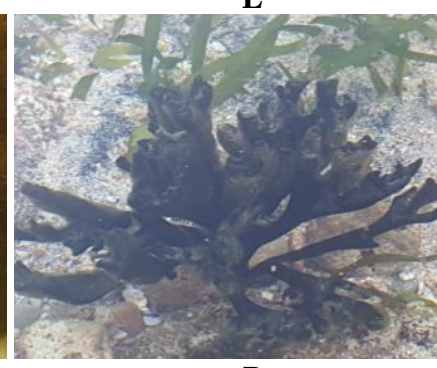

P

Figure 3. A. Axinella sp.; B. Raspailia arbuscula; C. Raspaciona sp.; D. Cervicornia sp.; E. Spheciospongia inconstans; F. Callyspongia sp.; G. Haliclona sp.; H. Dendroxea sp.; I. Petrosia sp.; J. Myxilla sp.; K. Trachyteleia sp.; L. Homaxinella sp.; M. Paratetilla bacca N. Thymosiopsis sp.; O. Chondrilla sp.; P. Chondrosia sp.

The existence of conspicuous shallow-water sponges Calyspongia and Haliclona (Table 2) presumably indicates the suitability and adaptability of morphological characters to seagrass meadows i.e., a larger oscula of the sponges is presumed to provide greater protection and shelter against predation (Wulff 2008). Sponges also provide shelter to other organisms in seagrass meadows. Henkel and Pawlik (2005) reported that the sponges Calyspongia vaginalis and Niphates digitalis provide optimal sheltering, indicated by the abundance of brittle stars living within the sponges. A similar study conducted by Briceño-Vera et al. (2021) reported that the sponge Haliclona implexiformis hosted a higher number of macrofaunal assemblages compared to Amorphinopsis atlantica. The specimens Callyspongia sp. and Haliclona sp. (figure $3 \mathrm{~F}$ and $3 \mathrm{G}$ ) in our study possessed a similar morphological structure to that of $C$. vaginalis, $N$. digitalis and $H$. implexiformis (a massivebranched form with several tube-like oscular projections) but were different from that of A. atlantica which had a massive-encrusting form with a wide basal area and small oscula. Moreover, in the study by (Muzaki et al. 2019) echinoderms were recorded as a conspicuous species of macrofaunal assemblages at similar locations to our study in Pacitan. 

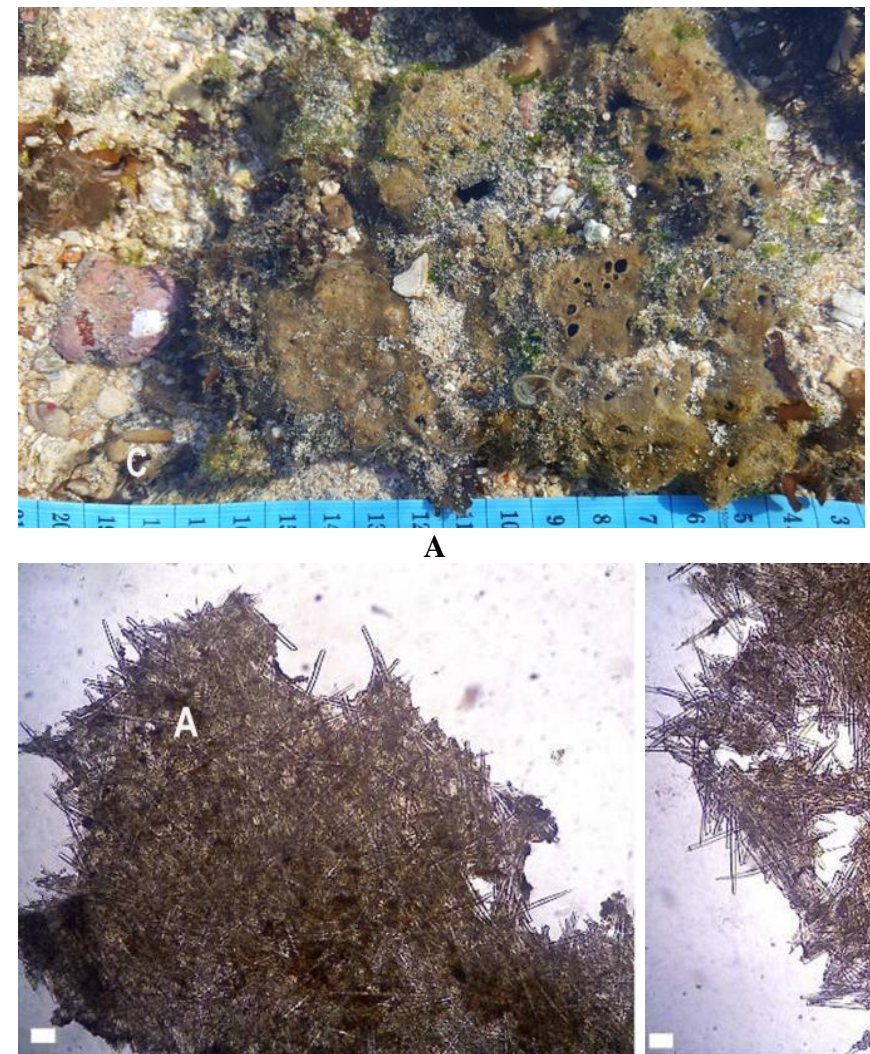

C

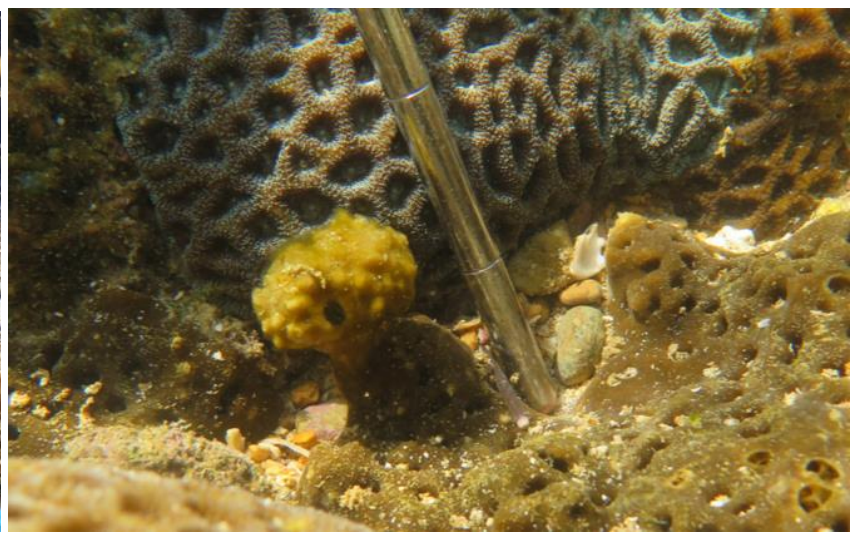

B

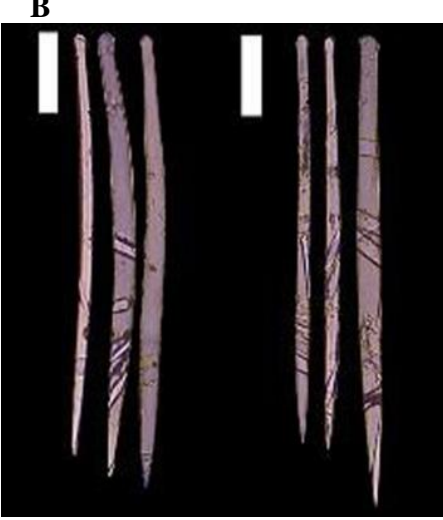

$\mathbf{E}$

Figure 4. A. Encrusted; B. Massive forms of S. inconstans; C-D. Skeleton of both encrusted and massive forms S. inconstans with numerous robust spicules forming a dense network; E. Tylotes spicules of both encrusted \& massive forms from $S$. inconstans (C-E, $1=100 \mu \mathrm{m})$

Table 2. Comparison of recorded species in this study to other results of sponges' associative seagrass in different localities

\begin{tabular}{|c|c|c|c|c|c|c|}
\hline Location & $\begin{array}{l}\text { Selected } \\
\text { location in } \\
\text { Pacitan } \\
(\text { This study) } \\
16 \text { sp, 16 } \\
\text { genera }\end{array}$ & $\begin{array}{c}\text { Southern } \\
\text { coast of Java } \\
\text { (Hadi et al. } \\
2018 \text { ) } \\
96 \mathrm{sp}, 49 \\
\text { genera } \\
\end{array}$ & $\begin{array}{c}\text { Pulau } \\
\text { Seribu } \\
\text { (Ismet et } \\
\text { al. 2017) } \\
\mathbf{1 8 ~ s p , ~ 1 3} \\
\text { genera } \\
\end{array}$ & $\begin{array}{c}\text { Mannar Gulf } \\
\text { and Palk Bay } \\
\text { India } \\
\text { (Sivaleela et al. } \\
\text { 2013) } \\
\text { 30 sp, 21 genera } \\
\end{array}$ & $\begin{array}{c}\text { Minicoy Atoll, } \\
\text { Lakshadweep, India } \\
\text { (Prabhakaran et al. } \\
\text { 2013) } \\
22 \text { sp, } 21 \text { genera }\end{array}$ & $\begin{array}{c}\text { Jervis Bay, } \\
\text { Australia } \\
\text { (Demers et } \\
\text { al. 2015) } \\
20 \text { sp, 20 } \\
\text { genera } \\
\end{array}$ \\
\hline Axinella sp. & + & -- & -- & + & -- & -- \\
\hline Raspailia arbuscula & + & -- & -- & -- & -- & -- \\
\hline Raspaciona sp. & + & -- & -- & -- & -- & -- \\
\hline Cervicornia sp. & + & -- & -- & -- & -- & -- \\
\hline Spheciospongia inconstans & + & + & + & -- & -- & -- \\
\hline Callyspongia sp. & + & + & + & + & + & + \\
\hline Haliclona sp. & + & + & + & + & + & + \\
\hline Dendroxea sp. & + & -- & -- & -- & -- & -- \\
\hline Petrosia sp. & + & + & -- & -- & -- & -- \\
\hline Myxilla sp. & + & -- & -- & -- & -- & -- \\
\hline Trachyteleia sp. & + & -- & -- & -- & -- & -- \\
\hline Homaxinella sp. & + & -- & -- & -- & -- & -- \\
\hline Paratetilla bacca & + & + & -- & -- & -- & -- \\
\hline Thymosiopsis sp. & + & -- & -- & -- & -- & -- \\
\hline Chondrilla sp. & + & -- & -- & -- & -- & -- \\
\hline Chondrosia sp. & + & -- & -- & -- & -- & -- \\
\hline
\end{tabular}

Note: +: present, --: absent 
Sponges have been investigated for their important role in marine ecosystems. Ecologically, they act as a filter for dissolved organic matter and because they live symbiotically with microbes, both sponges and holobiont are capable of assisting all the steps of the nitrogen cycle, acting as large sources of dissolved inorganic nitrogen (de Goeij et al. 2013). In addition, these nitrogen substances are utilized by seagrass for growth, while seagrass also provides protection for sponges (Wulff 2008). However, this sponge-seagrass meadows interaction needs further comprehensive investigation. Chronological studies by Archer et al. (2015) and Archer et al. (2018) displayed that the mutualistic symbiotic relationship between sponges and seagrass meadows has changed into commensalism and even to parasitism due to anthropogenic or environmental factors. Archer et al. (2015) demonstrated a commensal relationship between sponges and seagrass meadows despite Haliclona melanadocia sponges benefitting from coexistence with $T$. testudinum seagrasses. Furthermore, the interaction becomes more complex and contextdependent because the abundance of $H$. melanadocia is not linearly related to the abundance of $T$. testudinum. Archer et al. (2018) further corroborated their findings in 2015 on eutrophic conditions. In contrast to oligotrophic conditions, commensalism changes into parasitism when the development of $H$. melanadocia sponges become much slower due to the shading impact of $H$. melanadocia seagrass overgrowth. More importantly, Archer et al. (2018) stated that anthropogenic activities cause an influx in nutrition and in turn initiates an overgrowth of seagrasses population. Besides possessing a gentler beach in contrast to an open and stiff topography, Tawang beach also has been utilized as a traditional port for local fishers. Therefore, an influx of nutrients are entering the seagrass meadows and in turn increases the population and diversity of seagrasses and suppresses the population and diversity of sponges. This phenomenon initiates future research questions that need to be explored and investigated, for example, whether the composition and abundance among sponges at two different locations are influenced by the different compositions of seagrass meadows and whether or not ecological interactions between sponges and seagrass meadows at the two different locations is beneficial for both organisms.

In conclusion, we were able to conduct a pioneering study on the diversity of shallow-water sponges in the seagrass meadows of Pacitan that covered 16 genera out of 12 families. The Pacitan region is grouped into the Southern Java marine ecoregion (Spalding et al. 2007) and is categorized as a hotspot for seagrass biodiversity. The seagrass meadows of this region are categorized as ecosystems that are understudied and under-documented. In addition, the conditions and total area of seagrass meadows in this region are at threat due to increasing coastal populations and developments (Fortes et al. 2018). For this reason, exploring and monitoring the diversity of benthic-associated seagrass is important for future conservation since seagrasses are macrohabitats and microhabitats (Du et al. 2020). As macrohabitats, seagrass provides natural filters for adjacent and interconnected ecosystems like coral. In the localities of our study, coral reef ecosystems adjacent to seagrass meadows obtain benefits such as clear water filtered by seagrasses. As microhabitats, seagrass meadows provide nurseries for juveniles and in the localities of our study, sponge, fish and other invertebrate juveniles were able to utilize the meadows as a nursery ground. As microhabitats, seagrass meadows also provide foraging areas for reef organisms, and in our study, sponges species in the meadows such as $S$. inconstant and $P$. bacca were identified to interact with reef ecosystems as well as other invertebrates and fishes. Finally, as microhabitats, seagrass meadows become a refuge for marine fauna. In our study, a dense network of seagrass roots and shoots provided shelter and protection from predation for sponges, other invertebrates and fishes.

\section{ACKNOWLEDGEMENTS}

The authors gratefully acknowledge financial support from the Institut Teknologi Sepuluh Nopember, Surabaya, Indonesia for this work, under project scheme of the Publication Writing and PPHKI 2021. This Pacitan coastal project is also a part of collaborative research with the Department of Biology Education, Universitas PGRI Madiun (UNIPMA), Indonesia under the scheme of Penelitian Kerjasama Antar Perguruan Tinggi (PAKERTI) in 2018. We also appreciate the locals of Pidakan and Tawang coastal region, Pacitan, Indonesia that assisted in fieldwork and sampling. Moreover, we acknowledge Tri Aryono Hadi from the Research Center of Oceanography LIPI, Jakarta Lim Swee Cheng from the Tropical Marine Science Institute, National University of Singapore, and an anonymous reviewer who gave a constructive critics and suggestions while reviewing this manuscript. Likewise, to Arya Widya Dahana who proofread the final version of this publication.

\section{REFERENCES}

Anjum K, Abba SQ, Ali Shah SA, Akhter N, Batool S, ul Hassan SS. 2016. Marine sponges as a drug treasure. Biomol Therapeut 24 (4): 347-362. DOI: 10.4062/biomolther.2016.067.

Archer S, Stoner E, Layman C. 2015. A complex interaction between a sponge (Halichondria melanadocia) and a seagrass (Thalassia testudinum) in a subtropical coastal ecosystem. J Exp Mar Biol Ecol 465: 33-40. DOI: 10.1016/j.jembe.2015.01.003

Archer SK, Hensel E, Layman CA. 2018. Ambient nutrient availability drives the outcome of an interaction between a sponge (Halichondria melanadocia) and seagrass (Thalassia testudinum). J Exp Mar Biol Ecol 503: 86-91. DOI: 10.1016/j.jembe.2018.02.005

Becking LE, Cleary DFR, de Voogd NJ. 2013a. Sponge species composition, abundance, and cover in marine lakes and coastal mangroves in Berau, Indonesia. Mar Ecol Prog Ser 481: 105-120. DOI: $10.3354 /$ meps 10155

Becking LE, Erpenbeck D, Peijnenburg KT, de Voogd NJ. 2013 b. Phylogeography of the sponge Suberites diversicolor in Indonesia: Insights into the evolution of marine lake populations. PLoS One 8: e75996. DOI: 10.1371/journal.pone.0075996.

Bell JJ. 2008. The functional roles of marine sponges. Estuar Coast Shelf Sci 79: 341-353. DOI: 10.1016/j.ecss.2008.05.002.

Briceño-Vera AE, Ávila E, Rodríguez-Santiago MA, Ruiz-Marín A. 2021. Macrofaunal assemblages associated with two common seagrass-dwelling demosponges (Amorphinopsis atlantica and 
Haliclona implexiformis) in a tropical estuarine system of the southern Gulf of Mexico. Helgol Mar Res 75: 1. DOI: 10.1186/s10152-021-00546-z.

Calcinai B, Bastari A, Makapedua DM, Cerrano C. 2016. Mangrove sponges from Bangka Island (North Sulawesi, Indonesia) with the description of a new species. J Mar Biol Assoc UK 97: 1417-1422. DOI:10.1017/S0025315416000710.

Calcinai B, Bavestrello G, Bertolino M, Pica D, Wagner D, Cerrano C. 2013. Sponges associated with octocorals in the Indo-Pacific, with the description of four new species. Zootaxa 3617: 1-61. DOI: 10.1353/psc.2006.0026.

Dahihande A, Thakur N. 2017. Differential growth forms of the sponge Biemna fortis govern the abundance of its associated brittle star Ophiactis modesta. J Sea Res 126: 1-11. DOI: 10.1016/j.seares.2017.06.007.

de Goeij JM, van Oevelen D, Vermeij MJA, Osinga R, Middelburg JJ, de Goeij AFPM, Admiraal W. 2013. Surviving in a marine desert: The sponge loop retains resources within coral reefs. Sci 342: 108-110. DOI: $10.1126 /$ science. 1241981.

Demers M-CA, Knott NA, Davis AR. 2015. Under the radar: Sessile epifaunal invertebrates in the seagrass Posidonia australis. J Mar Biol Assoc U K 96: 363-377. DOI: 10.1017/S0025315415000612.

Dewi N, Prabowo S. 2015. Status padang lamun pantai-pantai wisata di Pacitan. Biogenesis: Jurnal Ilmiah Biologi 3: 53-59. DOI: 10.24252/bio.v3i1.567. [Indonesian]

Dewi N, Sasmito A, Aziz I, Sari K. 2019. Seagrass community at Tawang Coast Pacitan in rainy and dry season. J Phys Conf Ser 1175: 012007. DOI: 10.1088/1742-6596/1175/1/012007

Dohrmann M, Wörheide G. 2013. Novel scenarios of early anima evolution is it time to rewrite textbooks? Integr Comp Biol 53: 503 511. DOI: $10.1093 /$ icb/ict008.

Du J, Hu W, Nagelkerken I, Sangsawang L, Loh KH, Ooi JL-S, Liao J, Zheng X, Qiu S, Chen B. 2020. Seagrass meadows provide multiple benefits to adjacent coral reefs through various microhabitat functions. Ecosyst Health Sustain 6: 1812433. DOI: 10.1080/20964129.2020.1812433.

Edgar GJ, Alexander TJ, Lefcheck JS, Bates AE, Kininmonth SJ, Thomson RJ, Duffy JE, Costello MJ, Stuart-Smith RD. 2017. Abundance and local-scale processes contribute to multi-phyla gradients in global marine diversity. Sci Adv 3: e1700419. DOI: 10.1126/sciadv. 1700419 .

Fortes MD, Ooi JLS, Tan YM, Prathep A, Bujang JS, Yaakub SM. 2018 Seagrass in Southeast Asia: A review of status and knowledge gaps, and a road map for conservation. Bot Mar 61: 269-288. DOI: 10.1515/bot-2018-0008.

Guardiola M, Frotscher J, Uriz MJ. 2016. High genetic diversity, phenotypic plasticity, and invasive potential of a recently introduced calcareous sponge, fast spreading across the Atlanto-Mediterranean basin. Mar Biol 163: 123. DOI: 10.1007/s00227-016-2862-6.

Hadi TA, Hafitz M, Hadiyanto H, Budiyanto A, Siringoringo RM. 2018. Shallow water sponges along the south coast of Java, Indonesia. Biodiversitas 19 (2): 485-493. DOI: 10.13057/biodiv/d190223.

Henkel TP, Pawlik JR. 2005. Habitat use by sponge-dwelling brittlestars. Mar Biol 146: 301-313. DOI: 10.1007/s00227-004-1448-x

Hooper JNA. 2000. Sponguide: Guide to Sponge Collection and Identification in Systema Porifera. Kluwer Academic/Plenum Publishers, New York.

Ismet MS, Bengen DG, Radjasa OK, Kawaroe M. 2017. Composition and antibacterial activities of marine sponges from different seagrass ecosystems in Kepulauan Seribu Waters, Jakarta. Jurnal Ilmu dan Teknologi Kelautan Tropis 8: 729-745. DOI: 10.29244/jitkt. v8i2.15838.
Kim SK, Dewapriya P. 2012. Bioactive compounds from marine sponges and their symbiotic microbes: A potential source of nutraceuticals. Adv Food Nutr Res 65: 137-151. DOI: 10.1016/B978-0-12-4160033.00008-1.

Maas D, Prost S, de Leeuw C, Bi K, Smith L, Purwanto, Aji L, Tapilatu RF, Gillespie R, Becking L. 2020. Previously unidentified genetic structure revealed for the sponge Suberites diversicolor: Implications for sponge phylogeography and population genetics. Authorea Preprint, August 23, 2020. DOI: 10.22541/au.159818467.76147162.

McDonald J, Hooper J, McGuinness K. 2002. Environmentally influenced variability in the morphology of Cinachyra australiensis (Carter, 1886) (Porifera: Spirophorida: Tetillidae). Mar Freshw Res 53: 79-84. DOI: 10.1071/MF00153.

Muzaki F, Setiawan E, Insany G, Dewi N, Subagio I. 2019. Community structure of Echinoderms in seagrass beds of Pacitan beaches, East Java, Indonesia. Biodiversitas 20 (7): 1787-1793. DOI: 10.13057/biodiv/d200701.

Nava H, García-Madrigal CAE, Carballo JL. 2018. Relationships between boring sponge assemblages and the availability of dead coral substrate on Mexican Pacific coral reefs. J Mar Biol Assoc U K 99: 795-805. DOI: $10.1017 / \mathrm{S} 0025315418000899$.

Perdikaris S, Vlachogianni T, Valavanidis A. 2013. Bioactive natural substances from marine sponges: New developments and prospects for future pharmaceuticals. Nat Prod Chem Res 1: 3. DOI:10.4172/2329-6836.1000114.

Pianto HA. 2017. The legal efforts on marine culture development in Pacitan, 1999-2015. Indon Hist Stud 1: 78-90. DOI: 10.14710/ihis. v1i1.1241.

Pisani D, Pett W, Dohrmann M, Feuda R, Rota-Stabelli O, Philippe H, Lartillot N, Wörheide G. 2015. Genomic data do not support comb jellies as the sister group to all other animals. Proc Natl Acad Sci USA 112: 15402-15407. DOI: 10.1073/pnas.1518127112.

Prabhakaran M, Pillai N, Jayachandran P, Nandan SB. 2013. Species Composition and Distribution of Sponges (Phylum: Porifera) in the Seagrass Ecosystem of Minicoy Atoll, Lakshadweep, India Ecology and Conservation of Tropical Marine Faunal Communities. Springer, Berlin.

Santodomingo N, Becking LE. 2018. Unravelling the moons: Review of the genera Paratetilla and Cinachyrella in the Indo-Pacific (Demospongiae, Tetractinellida, Tetillidae). Zookeys 791: 1-46. DOI: 10.3897/zookeys.791.27546.

Sivaleela G, Vijay KD, Anbalagan T, Shrinivaasu S. 2013. Marine sponges of Gulf of Mannar and Palk Bay. Rec Zool Surv India 113: 17

Spalding MD, Fox HE, Allen GR, Davidson N, Ferdaña ZA, Finlayson M, Halpern BS, Jorge MA, Lombana A, Lourie SA, Martin KD, McManus E, Molnar J, Recchia CA, Robertson J. 2007. Marine ecoregions of the World: A bioregionalization of coastal and shelf areas. BioSci 57: 573-583. DOI: 10.1641/B570707.

van Soest RWM, de Voogd NJ. 2015. Calcareous sponges of Indonesia Zootaxa 3951: 1-105. DOI: 10.11646/zootaxa.3619.3.3.

van Soest RWM, Boury-Esnault N, Vacelet J, Dohrmann M, Erpenbeck D, de Voogd NJ, Santodomingo N, Vanhoorne B, Kelly M, Hooper JNA. 2012. Global diversity of sponges (Porifera). PLoS One 7: e35105. DOI: 10.1371/journal.pone.0035105

van Soest RWM, Boury-Esnault N, Hooper JNA, Rützler K, de Voogd NJ, de Glasby BA, Pisera AB, Manconi R, Schoenberg C, Janussen D, Tabachnick KR, Klautau M, Picton BE, Kelly M, Vacelet J, Dohrmann M, Díaz CM, Cárdenas P. 2018. World Porifera Database. http://www.marinespecies.org/porifera/.

Wulff JL. 2008. Collaboration among sponge species increases sponge diversity and abundance in a seagrass meadow. Mar Ecol 29: 193204. DOI: 10.1111/j.1439-0485.2008. 00224.x. 